\title{
CLINICAL SIGNIFICANCE OF PROCALCITONIN AND C-REACTIVE PROTEIN IN THE PREDICTION OF CARDIOVASCULAR COMPLICATIONS IN PATIENTS WITH TYPE 2 DIABETES MELLITUS
}

\author{
HANAA H AHMED ${ }^{1 *}$, WAFAA GH SHOUSHA ${ }^{2}$, HATEM A EL-MEZAYEN ${ }^{2}$, IBRAHIM A EMARA ${ }^{3}$, MARWA E HASSAN ${ }^{3}$ \\ ${ }^{1}$ Department of Hormones, National Research Centre, Giza, Egypt. ${ }^{2}$ Department of Biochemistry, Faculty of Science, Helwan University, \\ Cairo, Egypt. ${ }^{3}$ Department of Biochemistry, National Institute of Diabetes and Endocrinology, Cairo, Egypt. Email: hanaaomr@yahoo.com
}

Received: 03 May 2017, Revised and Accepted: 01 June 2017

\section{ABSTRACT}

Objective: This work was delineated to assess procalcitonin (PCT) and C-reactive protein (CRP) as prognostic markers for cardiovascular complication in type 2 diabetic patients.

Methods: Forty diabetic patients without cardiovascular disease (CVD), 40 diabetic patients with CVD, and 20 healthy control counterparts were participated in this study. Serum PCT and CRP levels were assayed and correlated with metabolic parameters. Receiver operating characteristic (ROC) curve analysis was done for each biochemical marker.

Results: The mean level of PCT was 707.17 $\pm 99.19 \mathrm{ng} / \mathrm{l}$ in diabetic patients versus $881.30 \pm 123.56 \mathrm{ng} / \mathrm{l}$ for the cardio-diabetic patients ( $\mathrm{p}<0.0001$ ). The mean value of CRP was $34.43 \pm 17.27 \mathrm{mg} / \mathrm{l}$ in diabetic patients versus $50.32 \pm 20.19 \mathrm{mg} / \mathrm{l}$ for the cardio-diabetic patients ( $\mathrm{p}=0.0003$ ). PCT levels were significantly amplified in the cardio-diabetic patients with increasing CRP, triglycerides (TG), fasting blood glucose (FBG), and cholesterol $(\mathrm{p}=0.004,0.0005,0.002$, and 0.01 , respectively). CRP levels were significantly enhanced in the cardio-diabetic patients with increasing TG, FBG, cholesterol, and microalbumin ( $\mathrm{p}=0.002,0.047,0.003$, and 0.001 respectively). ROC curve analysis for PCT and CRP revealed that the area under curve (AUC) was 0.878 and 0.727 , respectively. These findings indicate the good validity of the above biomarkers especially PCT as a prognostic marker for cardiovascular complication in type 2 diabetic patients.

Conclusion: This study evidences the usefulness of measuring serum levels of PCT and CRP in diagnosis of cardiovascular complication in type 2 diabetic patients.

Keywords: Procalcitonin, Diabetes mellitus, C-reactive protein, Cardiovascular complications.

(c) 2017 The Authors. Published by Innovare Academic Sciences Pvt Ltd. This is an open access article under the CC BY license (http://creativecommons. org/licenses/by/4. 0/) DOI: http://dx.doi.org/10.22159/ajpcr.2017.v10i9.19524

\section{INTRODUCTION}

Diabetes mellitus is a chronic disease that affects 415 million people worldwide, and 5 million people died from diabetic complications [1]. Type 2 diabetes mellitus (T2DM) is manifested by hyperglycemia that results from lack of insulin or resistance to the action of insulin in the muscle, fat, and liver in addition to an inadequate response by the pancreatic beta cells [2].

Uncontrolled diabetes for the first few years can cause acute cardiac and renal complications which are life-threatening, whereas poorly controlled diabetes can cause long-term cardiac and renal complications [3]. This is due to a complex group of risk factors associated with T2DM including insulin resistance, hyperglycemia, diabetic dyslipidemia, hypertension, hyperinsulinemia, systemic inflammation, and adipose tissue-derived factors [4-6]. Worth mentioning, the changes in the mass and metabolism of adipose tissue may be paralleled by insulin resistance and visceral obesity commonly associated with T2DM [7].

Inflammatory mediators play a critical role in the development of cardiovascular disease (CVD). In particular, acute coronary syndrome (ACS) is an inflammatory disease and the serum levels of inflammatory factors, such as interleukin (IL)-6, IL-18 and C-reactive protein (CRP), are used to detect patients with CVD, especially coronary artery disease (CAD) [8]. Moreover, CRP has been found to be significantly elevated in patients with acute myocardial infarction [9].

CRP is a well-known acute inflammatory marker that has been used as a mediator of infection [10]. These two factors are easy in assessment, reliable, and inexpensive, and they are used for the diagnosis and follow-up of several diseases $[10,11]$. Procalcitonin (PCT) is produced during bacterial infections, sepsis, cardiogenic shock, major surgery, burns, multiple trauma, and after cardiac surgery $[12,13]$. It is a hormone of 116 amino acids and it is implicated in calcium metabolism. First, it is recognized as prohormone of calcitonin, which is synthesized by the medullary C-cells of the thyroid gland [14-16]. Nonetheless, even thyroidectomized patients showed PCT response during acute inflammation [17] indicating that there are other probable origins of PCT production.

Some investigators have suggested that PCT may be produced by the liver and inflammatory cells $[18,19]$. The inflammatory response is an essential feature of ACS and myocardial infarction (MI). In acute MI (AMI), signs of inflammation are well identified and the amplified levels of acute phase reactants have been found to be linked to a worse short- and long-term prognosis [20]. Signs of the systemic inflammatory response, such as fever, leukocytosis, and the enhanced acute-phase reactants, are frequently shown in patients with ACS [21]. PCT has been manifested as a novel cardiac marker in AMI [22]. Circumstantial evidence showed that bacterial endotoxins and tumor necrosis factor- $\alpha$ (TNF- $\alpha$ ) both induced PCT in vitro $[13,23]$. Based on this document, PCT may be considered as an alternative new valuable prognostic marker in ACS. Many research studies have cited higher PCT levels in patients versus healthy controls following severe sepsis, cardiac surgery, or trauma [24-26].

The focus of our interest was to detect the kinetics of procalcitonin production, compared with CRP, as a novel prognostic marker for cardiovascular complications in type 2 diabetic patients. 


\section{METHODS}

Forty diabetic patients with CVD (cardio-diabetic group) and forty diabetic patients without evidence of CVD (diabetic group) wereincluded in the current study. In addition, twenty healthy participants who with no history of T2DM, other endocrine dysfunctions, hyperlipidemia, hypertension, or coronary heart diseases (CHDs) were enrolled in the study and served as controls. Clinical evidence of CVD included MI or coronary artery bypass surgery, stroke, and peripheral arterial disease. Patients in the group without vascular disease were T2DM patients who had no history of vascular disease and those with normal electrocardiogram findings at exercise and normal peripheral artery Doppler ultrasonography. Exclusion criteria involved the presence of sustained Type $1 \mathrm{DM}$, acute and chronic infections, malignancy, hepatic or renal disease, diabetic retinopathy and nephropathy, and other endocrine dysfunctions. This study was approved by Ethical Committee of Ethics Commission and Scientific Research of the General Authority for Hospitals and Educational Institutes.

Venous blood and urine samples were collected from all participants and each blood sample was divided into two portions. The small portion was collected on EDTA-coated tube and the large portion was collected on EDTA-free coated tube. Serum samples were obtained by centrifugation and the biochemical variables were measured on the same day of the blood collection. Remaining serum specimens were stored at $-20^{\circ} \mathrm{C}$ until analysis of PCT and CRP levels.

Quantitative determination of serum glucose was carried out colorimetrically using commercial kits purchased from Randox Laboratories (Crumlin, County Antrim, United Kingdom) using method of Thomas [27]. Quantitative estimation of serum cholesterol was done colorimetrically using commercial kits purchased from Randox Laboratories using method of Richmond [28]. Serum high density lipoprotein (HDL)-cholesterol was assayed colorimetrically using commercial kits purchased from Randox Laboratories using method of Assmann [29]. Low density lipoprotein (LDL)-cholesterol was quantified in serum using a kit provided by Spinreact (Girona, Spain) for the quantitative determination of serum LDL-cholesterol following the method of Okada et al. [30]. Triglycerides (TG) in serum were measured colorimetrically using commercial kit purchased from Randox Laboratories according the method of Jacobs and Van Denmark [31]. Glycated hemoglobin was determined using a kit provided by Spinreact for the quantitative determination of glycated hemoglobin according to the method described by Trivelli et al. [32]. Serum CRP was measured by ELISA using commercial kit purchased from Immunospec Corporation (Canoga Park, USA) following the method of Hedlund [33]. Quantitative estimation of microalbumin in urine was done by immunoturbidimetric assay using commercial kit purchased from Pointe Scientific, INC (Canton, USA) according to the method of Mogensen and Schmitz [34]. Serum PCT was evaluated by solid phase enzyme-linked immunosorbent assay (ELISA kit) using 96-well microplates supplied by Glory Science Co., Ltd (Del Rio, USA) in accordance with the method described by Arkader et al. [35].

\section{Statistical analysis}

Data were expressed as mean \pm standard deviation and analyzed using MedCalc software, version 11. The Student's t-test was used to assess the significance of difference in the levels of PCT and CRP between the patient groups (diabetic and cardio-diabetic) and the control group. The correlation analysis between serum PCT and CRP level and other measured parameters in the different studied groups was done by correlation coefficient test. The cut-off value was determined for each of the studied parameters in the current study according to the best discrimination between diabetic patients and cardio-diabetic patients regarding optimal values of sensitivity and specificity using receiver operating characteristic (ROC) curves analysis. Area under the curve (AUC) of the ROC curve was calculated for each test. $\mathrm{p}<0.05$ was accepted as significant.

\section{RESULTS}

Laboratory assessments of the measured parameters in the different submitted groups are presented in Table 1. Cholesterol, CRP, FBG, hemoglobin A1c (HbA1c), LDL, TG, microalbumin, and PCT levels were significantly higher in diabetic patients than in healthy individuals $(\mathrm{p}=0.022, \mathrm{p}<0.0001, \mathrm{p}<0.0001, \mathrm{p}<0.0001, \mathrm{p}=0.042, \mathrm{p}=0.007, \mathrm{p}=0.016$, and $\mathrm{p}<0.0001$, respectively). Likewise, CRP, FBG, HbA1c, LDL, TG, cholesterol, PCT, and microalbumin levels were significantly higher in cardio-diabetic patients than in healthy individuals $(\mathrm{p}<0.0001$, $\mathrm{p}<0.0001, \mathrm{p}<0.0001, \mathrm{p}<0.0001, \mathrm{p}=0.009, \mathrm{p}=0.007, \mathrm{p}<0.0001$, and $\mathrm{p}<0.0001$, respectively). In addition, CRP, LDL, PCT, and microalbumin levels were significantly higher in cardio-diabetic patients as compared to diabetic patients $(\mathrm{p}=0.0003, \mathrm{p}<0.0001, \mathrm{p}<0.0001$, and $\mathrm{p}<0.0001$, respectively). Whereas, HDL level showed significant drop in cardiodiabetic patients versus diabetic patients and controls $(\mathrm{p}=0.0002$ and $\mathrm{p}<0.0001$, respectively). Furthermore, it revealed significant decline in diabetic patients relative to healthy participants $(\mathrm{p}=0.038)$ (Table 1$)$.

The results of correlation between serum PCT concentration and metabolic parameters in the different studied groups are depicted in Table 2. Significant positive correlation between serum PCT

Table 1: Laboratory assessments in the different studied groups

\begin{tabular}{|c|c|c|c|c|c|c|}
\hline Parameters & Control subject (C) & Diabetic patients (D) & Cardio-diabetic patients (CD) & P1 & $\mathbf{P} 2$ & P3 \\
\hline \multirow[t]{2}{*}{ Cholesterol (mg/dl) } & $194.15 \pm 36.70$ & $225.70 \pm 54.40$ & $233.02 \pm 57.47$ & 0.022 & 0.007 & 0.56 \\
\hline & $140.00-252.00$ & $135.00-383.00$ & $69.00-378.00$ & & & \\
\hline \multirow[t]{2}{*}{ CRP (mg/l) } & $14.53 \pm 6.92$ & $34.43 \pm 17.27$ & $50.32 \pm 20.19$ & $<0.0001$ & $<0.0001$ & 0.0003 \\
\hline & $4.80-25.10$ & $16.10-75.30$ & $19.20-89.80$ & & & \\
\hline \multirow[t]{2}{*}{ FBG (mg/dl) } & $87.40 \pm 6.91$ & $256.07 \pm 101.2$ & $272.80 \pm 103.09$ & $<0.0001$ & $<0.0001$ & 0.466 \\
\hline & $75.00-101.00$ & $105.00-589.00$ & $127.00-606.00$ & & & \\
\hline HbA1c (\%) & $5.45 \pm 0.51$ & $9.74 \pm 1.67$ & $10.16 \pm 2.10$ & $<0.0001$ & 0.0001 & 0.325 \\
\hline \multirow[t]{2}{*}{ HDL (mg/dl) } & $40.25 \pm 7.67$ & $35.35 \pm 8.8$ & $27.57 \pm 8.83$ & 0.038 & $<0.0001$ & 0.0002 \\
\hline & $28.00-55.00$ & $10.00-47.00$ & $15.00-45.00$ & & & \\
\hline \multirow[t]{2}{*}{ LDL (mg/dl) } & $122.90 \pm 25.04$ & $146.25 \pm 46.94$ & $202.47 \pm 36.48$ & 0.042 & $<0.0001$ & $<0.0001$ \\
\hline & $77.00-159.00$ & $64.00-278.00$ & $118.00-298.00$ & & & \\
\hline \multirow[t]{2}{*}{ TG (mg/dl) } & $121.60 \pm 55.44$ & $183.47 \pm 91.76$ & $237.70 \pm 187.56$ & & & \\
\hline & $75.00-307.00$ & $35.00-417.00$ & $71.00-981.00$ & 0.007 & 0.009 & 0.104 \\
\hline \multirow[t]{2}{*}{ Procalcitonin (ng/l) } & $381.67 \pm 140.2$ & $707.17 \pm 99.19$ & $881.30 \pm 123.56$ & $<0.0001$ & $<0.0001$ & $<0.0001$ \\
\hline & $200.50-642.20$ & $505.0-880.0$ & $610.0-1150.0$ & & & \\
\hline Microalbumin (mg/ml) & $0.60-12.0$ & $0.30-31.10$ & $8.28-68.90$ & & & \\
\hline
\end{tabular}

P1: Diabetic group compared to control group. P2: Cardio-diabetic group compared to control group. P3: Cardio-diabetic group compared to diabetic group. CRP: C-reactive protein, FBG: Fasting blood glucose, HbA1c: Hemoglobin A1c, HDL: High-density lipoprotein, LDL: Low-density lipoprotein, TG: Triglycerides 
concentration and cholesterol, TG, CRP, and FBG has been determined in cardio-diabetic patients $(\mathrm{p}=0.011, \mathrm{p}=0.0005, \mathrm{p}=0.004$, and $\mathrm{p}=0.002$, respectively). As well, significant positive correlation between serum PCT concentration and LDL, cholesterol, TG, CRP, FBG, and HbA1C has been recorded in diabetic patients $(\mathrm{p}=0.052, \mathrm{p}=0.013, \mathrm{p}=0.003$, $\mathrm{p}<0.0001, \mathrm{p}<0.0001$, and $\mathrm{p}=0.009$, respectively). However, significant negative correlation has been observed between serum PCT and microalbumin in diabetic patients ( $\mathrm{p}=0.016)$ (Figs. 1 and 2).

The data of correlation between serum CRP level and other measured biochemical markers in the different studied groups are illustrated in Table 3. Significant positive correlation between serum CRP level and cholesterol, TG, FBG, PCT, and microalbumin in cardio-diabetic patients has been demonstrated $(\mathrm{p}=0.003, \mathrm{p}=0.002, \mathrm{p}=0.047, \mathrm{p}=0.004$, and $\mathrm{p}=0.001$, respectively). Similarly, significant positive correlation between serum CRP level and LDL, cholesterol, TG, FBG, HbA1c, and PCT has been detected in diabetic patients $(p=0.004, p=0.001, p=0.004$, $\mathrm{p}=0.0001, \mathrm{p}=0.047$, and $\mathrm{p}<0.0001$, respectively). Meanwhile, significant negative correlation has been recorded between serum CRP level and HDL and microalbumin in diabetic patients $(\mathrm{p}=0.047$ and $\mathrm{p}=0.018$, respectively) (Figs. 3 and 4).

The receiving operating characteristic (ROC) curve is designed for PCT and CRP (Figs. 5 and 6). The cut-off values for PCT and CRP were $750 \mathrm{ng} / \mathrm{l}$, and $42.1 \mathrm{mg} / \mathrm{l}$, respectively. AUC for PCT and CRP was 0.878 and 0.727 , respectively. This result indicated the good validity of the above biochemical markers particularly PCT to discriminate diabetic patients from cardio-diabetic patients.

\section{DISCUSSION}

Type 2 diabetic patients have a high risk for CVD. This risk is accompanied by many factors such as hypertension, dyslipidemia, and obesity in these patients. However, the onest of CVD in type 2 diabetic patients is not linked with the high prevalence of traditional risk factors only, but other non-traditional risk factors may be implicated.
Thus, CVD is increased in type 2 diabetic patients due to a complex combination of various traditional and non-traditional risk factors. This has a critical role to play in the evolution of atherosclerosis over its long natural history from endothelial function to clinical events [36]. The objective of this study was to assess PCT and CRP as prognostic markers for cardiovascular complications in patients with T2DM.

The results obtained in this study showed that cholesterol, LDL, and TG are significantly increased in diabetic patients relative to controls whereas, HDL is significantly decreased in diabetic patients versus the controls. These results are in conformity with those of Ali and Al Hadidi [37] who stated that all the above parameters are significantly higher in T2DM group, whereas HDL is significantly lower in T2DM group in respect with the control group. These results are explained by Ronald [38] who cited that insulin resistance may contribute in the development of dyslipidemia in diabetic patients. As in type 2 diabetes, insulin resistance increases the flow of free fatty acids from adipose tissue and impairs insulin-mediated skeletal muscle uptake of free fatty acids resulting in increased fatty acid flow to the liver $[39,40]$. The increased free fatty acid levels in individuals with impaired glucose tolerance suggesting that insulin resistance is related to the elevated free fatty acid levels which occur before the onset of hyperglycemia [41]. Many investigators have demonstrated a relationship between plasma free fatty acid levels and insulin resistance [42]. Free fatty acids in the form of TG are deposited in the muscle, liver, heart, and pancreas in the presence of insulin resistance. Furthermore, insulin resistance increases the activity of hepatic lipase, which is responsible for hydrolysis of phospholipids into LDL and HDL particles with consequent formation of very small and dense LDL particles and a reduction in HDL particles [43,44]. This hypothesis is appreciated when some drugs that lowered the high level of free fatty acids (thiazolidinediones) could improve insulin sensitivity in the muscle, liver, and adipose tissues $[45,46]$.

FBG and HbA1c levels are significantly enhanced in diabetic patients comparing with healthy individuals. These results are in harmony with

Table 2: Correlation between serum procalcitonin concentration and metabolic parameters in the different studied groups

\begin{tabular}{|c|c|c|c|c|c|c|}
\hline \multirow[t]{2}{*}{ Parameters } & \multicolumn{2}{|c|}{$\begin{array}{l}\text { Serum procalcitonin level } \\
\text { in control groups }\end{array}$} & \multicolumn{2}{|c|}{$\begin{array}{l}\text { Serum procalcitonin level } \\
\text { in diabetic group }\end{array}$} & \multicolumn{2}{|c|}{$\begin{array}{l}\text { Serum procalcitonin level } \\
\text { in cardio-diabetic groups }\end{array}$} \\
\hline & $\mathbf{r}$ & $\mathbf{p}$ & $\mathbf{r}$ & $\mathbf{p}$ & $\mathbf{r}$ & $\mathbf{p}$ \\
\hline Cholesterol (mg/dl) & 0.231 & 0.325 & 0.385 & $0.013^{*}$ & 0.395 & $0.011^{*}$ \\
\hline $\mathrm{TG}(\mathrm{mg} / \mathrm{dl})$ & 0.688 & $0.0008^{* *}$ & 0.448 & $0.003^{* *}$ & 0.524 & $0.0005^{* *}$ \\
\hline HDL (mg/dl) & 0.245 & 0.296 & -0.281 & 0.078 & 0.207 & 0.198 \\
\hline $\mathrm{LDL}(\mathrm{mg} / \mathrm{dl})$ & 0.132 & 0.576 & 0.308 & $0.052^{*}$ & 0.185 & 0.250 \\
\hline $\mathrm{CRP}(\mathrm{mg} / \mathrm{l})$ & -0.133 & 0.575 & 0.760 & $<0.0001^{* *}$ & 0.437 & $0.004^{* *}$ \\
\hline FBG (mg/dl) & -0.416 & 0.068 & 0.718 & $<0.0001^{* *}$ & 0.470 & $0.002^{* *}$ \\
\hline $\operatorname{HbA1c}(\%)$ & 0.337 & 0.146 & 0.4036 & $0.009^{* *}$ & 0.211 & 0.190 \\
\hline Microalbumin (mg/ml) & 0.230 & 0.327 & -0.377 & $0.016^{*}$ & 0.292 & 0.067 \\
\hline
\end{tabular}

$\mathrm{r}=$ Correlation coefficient, ${ }^{*} \mathrm{p}<0.05,{ }^{* *} \mathrm{p}<0.01$, not significant (p>0.05). CRP: C-reactive protein, FBG: Fasting blood glucose, HbA1c: Hemoglobin A1c, HDL: High-density lipoprotein, LDL: Low-density lipoprotein, TG: Triglycerides

Table 3: Correlation between serum CRP level and and metabolic parameters in the different studied groups

\begin{tabular}{|c|c|c|c|c|c|c|}
\hline \multirow[t]{2}{*}{ Parameters } & \multicolumn{2}{|c|}{$\begin{array}{l}\text { Serum CRP level in } \\
\text { control groups }\end{array}$} & \multicolumn{2}{|c|}{$\begin{array}{l}\text { Serum CRP level in } \\
\text { diabetic group }\end{array}$} & \multicolumn{2}{|c|}{$\begin{array}{l}\text { Serum CRP level in } \\
\text { cardio-diabetic groups }\end{array}$} \\
\hline & $\mathbf{r}$ & $\mathbf{p}$ & $\mathbf{r}$ & $\mathbf{p}$ & $\mathbf{r}$ & $\mathbf{p}$ \\
\hline Cholesterol (mg/dl) & 0.490 & $0.028 *$ & 0.476 & $0.001^{* *}$ & 0.446 & $0.003^{*}$ \\
\hline $\mathrm{TG}(\mathrm{mg} / \mathrm{dl})$ & 0.327 & 0.158 & 0.442 & $0.004^{*}$ & 0.471 & $0.002^{*}$ \\
\hline HDL (mg/dl) & 0.278 & 0.234 & -0.315 & $0.047^{*}$ & -0.119 & 0.463 \\
\hline LDL (mg/dl) & 0.265 & 0.257 & 0.444 & $0.004^{*}$ & 0.240 & 0.135 \\
\hline FBG (mg/dl) & -0.049 & 0.844 & 0.588 & $0.0001^{* *}$ & 0.315 & $0.047^{*}$ \\
\hline HbA1c $(\%)$ & -0.265 & 0.258 & 0.315 & $0.047^{*}$ & 0.095 & 0.558 \\
\hline Microalbumin (mg/ml) & 0.530 & $0.016^{*}$ & -0.370 & $0.018^{*}$ & 0.491 & $0.001^{* *}$ \\
\hline Procalcitonin (ng/l) & -0.133 & 0.575 & 0.760 & $<0.0001^{* *}$ & 0.437 & $0.004^{* *}$ \\
\hline
\end{tabular}

$\mathrm{r}=$ Correlation coefficient, ${ }^{*} \mathrm{p}<0.05,{ }^{* *} \mathrm{p}<0.01$, not significant ( $>00.05$ ). CRP: C-reactive protein, FBG: Fasting blood glucose, HbA1c: Hemoglobin A1c, HDL: High-density

lipoprotein, LDL: Low-density lipoprotein, TG: Triglycerides 


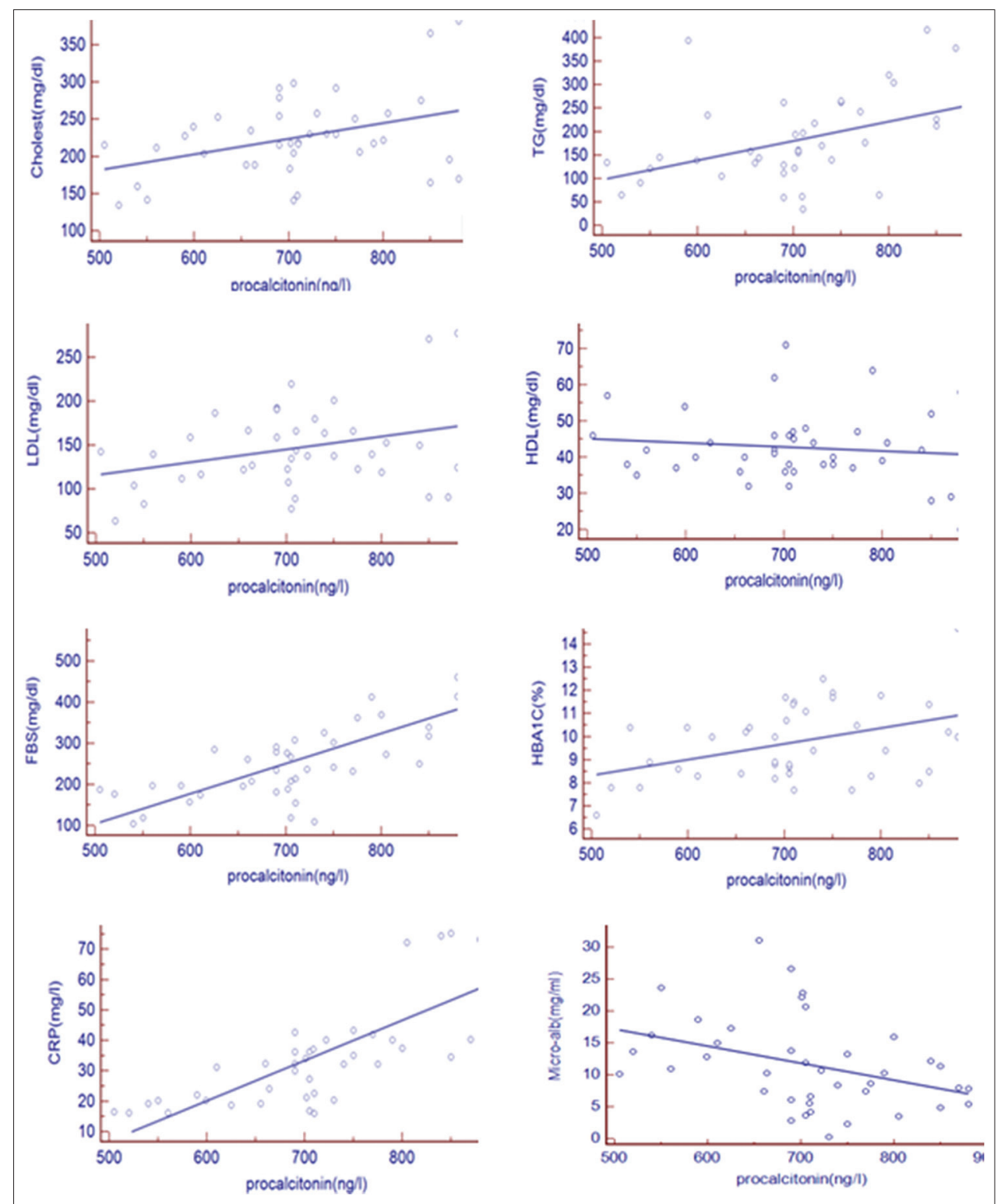

Fig. 1: Correlation between different metabolic parameters and serum procalcitonin concentration in diabetic group

the study of Ali and Al Hadidi [37] who revealed that FBG and HbA1C levels are significantly higher in diabetic patients than in healthy individuals. Furthermore, Makris et al. [47] recorded a significant relation between FBG and HbA1C in diabetic patients. The studies of Peterson et al. [48] and Miedema [49] have shown that the increased blood glucose leads to the increased attachment of glucose molecules to the hemoglobin in red blood cells. The long period of hyperglycemia in the blood, the more glucose binds to hemoglobin in the red blood cells and the higher in glycated hemoglobin. It is formed in a non-enzymatic glycationgly pathway of hemoglobin exposure to plasma glucose; then, reaction occurs between glucose and the $\mathrm{N}$-end of the beta chain in hemoglobin. In diabetes mellitus, higher amounts of glycated hemoglobin indicating a poorer control of blood glucose levels with consequent complications such as CVD, nephropathy, neuropathy, and retinopathy.

CRP level is significantly elevated in diabetic patients relative to healthy individuals. These results are in keeping with those of Belfki et al. [50] who demonstrated that levels of CRP are significantly elevated in patients with T2DM versus controls. Morohoshi et al. [51] and Guha et al. [52] mentioned that hyperglycemia stimulates the liberation of the inflammatory cytokine such as IL- 6 and TNF- $\alpha$ from different cell types and results in the secretion of acute phase reactants by adipocytes. Grunfeld et al. [53] and Hirschfield et al. [54] proved that CRP is an acute phase reactant that is produced primarily in the liver under the activation of adipocyte-derived proinflammatory cytokines.

Serum PCT level is significantly amplified in diabetic patients relative to controls. Our results are in harmony with those of Soylemez et al. [55] who reported that PCT levels are elevated in type 2 diabetic patients compared with healthy controls. In addition, Schiopu et al. [56] found that PCT is positively correlated with the presence of hyperglycemia and with systolic blood pressure. Moreover, hyperglycemia is accompanied by increased systemic inflammatory activation and thus, it seems that this inflammation may stimulate PCT production.

These investigators explained the elevated levels of PCT in type 2 diabetic patients by the fact that T2DM is related to oxidative stress and advanced glycation end-products (AGEs) elevation. AGEs interact with its receptor called RAGE. Potentiation of RAGE leads to regulation of the transcription factor, nuclear factor-kB, and its target genes and also of activator protein-1(AP-1). These factors could ultimately lead to upregulation of PCT gene expression. 


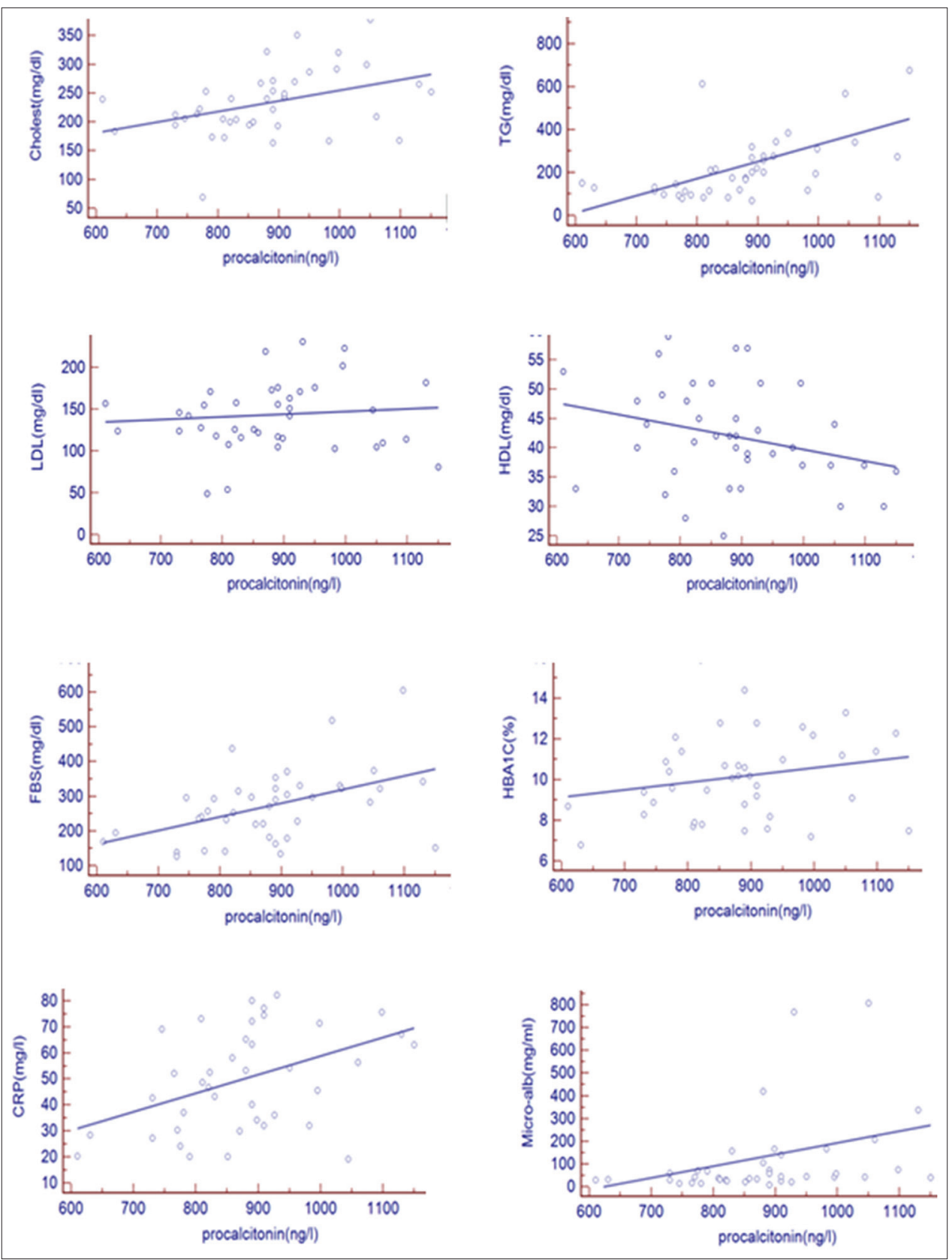

Fig. 2: Correlation between different metabolic parameters and serum procalcitonin concentration in cardio-diabetic group

There are significantly higher differences in microalbumin between diabetic patientsand controls. These findings echo those of perviousstudy of Chowta et al. [57] who found high prevalence of microalbuminuria (37\%) in T2DM, and the incidence of microalbuminuria increases with the increased duration of diabetes mellitus. Mogensen et al. [58] proved a positive correlation between microalbuminuria and the duration of diabetes mellitus. Long duration of diabetes has significant contribution for the development of microalbuminuria. Prolonged exposure to hyperglycemia causes AGEs accumulation. Bucala et al. [59] and Tan et al. [60] stated that hyperglycemia may cause tissue damage by several mechanisms, one of which is non-enzymatic glycation of intra- and extra-cellular proteins. Glucose has a reactive aldehyde moiety which reacts non-enzymatically with the amino groups of proteins in the extracellular matrix, producing reversible Amadori products, and AGEs that can impair degradation of proteins, and induce cytotoxic pathways. Hence, serum levels of AGEs increased in type 2 diabetic patients, and this leads to increased level of microalbumin.
Cholesterol, TG, and LDL are significantly increased in cardio-diabetic group relative to healthy control group. Meanwhile, HDL is significantly decreased in cardio-diabetic patients versus healthy individuals. This finding is in respect with the study of Haddad et al. [61] who found that cholesterol, LDL-C, and TG levels are increased but HDL-C level is decreased in diabetic patients with CAD compared with those in control group. These data are explained by Celermajer [62] who mentioned that dyslipidemia is a critical mechanism by which atherosclerosis and endothelial dysfunction can occur in diabetic patients. Healthy endothelium regulates activation of platelet, tone of the blood vessel, leukocyte adhesion, inflammation, and thrombogenesis. Thus, healthy endothelium is antiatherogenic, vasodilatory, and antiinflammatory [62]. Affection of these mechanisms results in the generation of atherosclerosis. Therefore, both insulin resistance and insulin deficiency lead to dyslipidemia accompanied by increased glycosylation, oxidation, and TG enrichment of lipoproteins. 


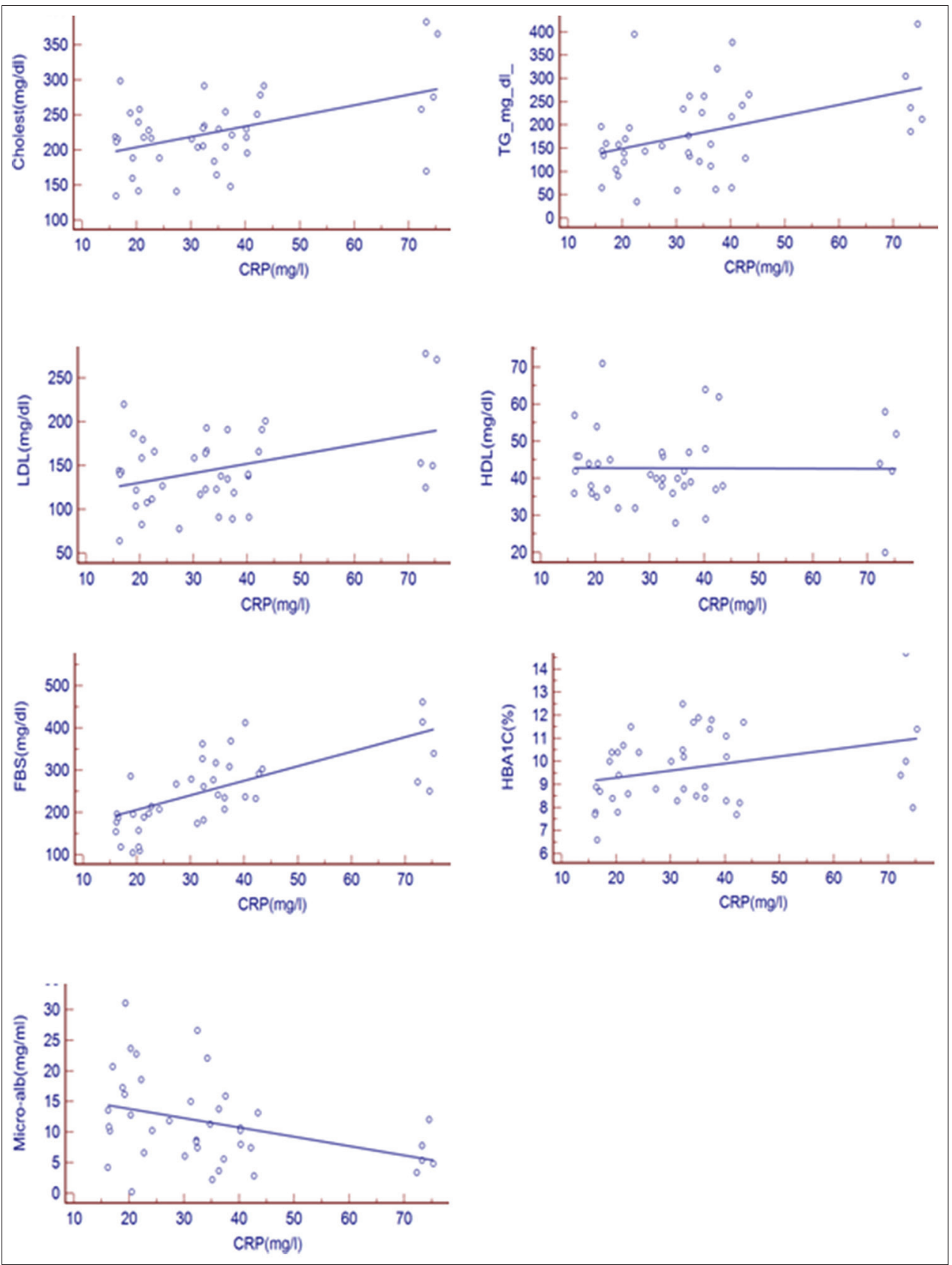

Fig. 3: Correlation between different metabolic parameters and serum C-reactive protein level in diabetic group

Furthermore, Dokken [63] has shown that oxidized LDL is proatherogenic because when the particles of LDL are oxidized, they showed new properties that are recognized by the immune system as "foreign." Furthermore, oxidized LDL induces many abnormal biological responses, such as promoting the capability of leukocytes to ingest lipids and differentiate into foam cells, attracting leukocytes to the intima of the vessel, and stimulating leukocytes, endothelial cells (ECs), and smooth muscle cell (SMC) proliferation [64]. All of these results in the generation of atherosclerotic plaque. Furthermore, in diabetic patients, LDL particles can glycated, in a process similar to the glycation of hemoglobin. Glycation of LDL prolongs its half-life [65] and therefore increased the capability of LDL to induce atherogenesis.

FBG and HbA1C levels are significantly elevated in cardio-diabetic patients relative to the controls. These results are in harmony with those of Anping et al. [66] who stated that levels of HbA1C are gradually increased in unstable angina (UA) and AMI patients versus healthy individuals. Biologically, glycated hemoglobin is an advanced glycosylation end-product, and the increased level of HbA1C causes the formation of advanced glycosylation end-product, which attaches to the vessel wall and leads to dysfunction of endothelium and oxidative stress progression $[67,68]$. Furthermore, the binding of advanced glycosylation end-product is associated with overproduction of inflammatory mediators like CRP [69]. Increased CRP level has been shown to be significantly linked with the instability of plaque $[70,71]$. This explains why that after adjustifying CRP, there is no significant association between HbA1c and the severity of CAD. Finally, increased level of advanced glycosylation end-product interferes with the endogenous fibrinolytic system which may lead to high risk of coronary artery stenosis [72]

CRP is significantly elevated in cardio-diabetic patients in respect to healthy individuals. Our results come in line with those of Ridker [73] who proved that the increased level of CRP is related to an 8-fold increase 


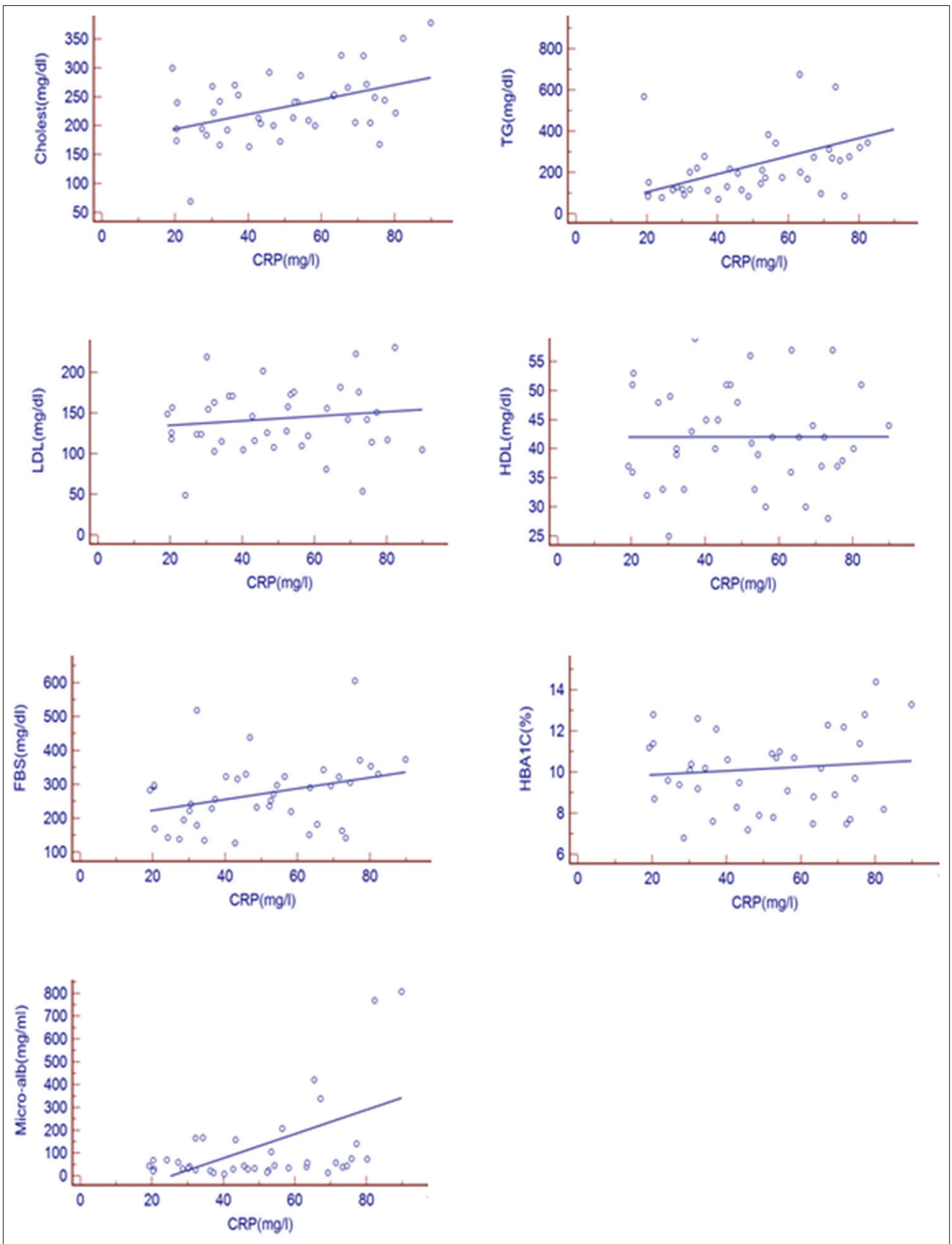

Fig. 4: Correlation between different metabolic parameters and serum C-reactive protein level in cardio-diabetic group

in cardiovascular mortality. Furthermore, Liang et al. [74] stated that the level of CRP is significantly enhanced in AMI and UA patients than in stable angina patients and healthy control. These observations are interpreted by Shrivastava et al. [75] who reported that atherosclerotic process is characterized by low-grade inflammation and increased level of the inflammatory modulators. In addition, CRP is also generated locally the in atherosclerotic lesions by inflamed SMCs lymphocytes and monocytic cells.

Paffen and DeMaat [76] and Pfützner et al. [77] found that CRP plays a critical role in many aspects of atherogenesis including activation of the classical pathway of the complement system. Through this action, CRP directly facilitates the innate immunity, a process that has already been related to the development and progression of CHD [77]. CRP increases LDL uptake into macrophages and enhances the capability of macrophages to form foam cells. Moreover, CRP upregulates adhesion molecules expression in ECs that can attract monocytes to the site of injury. Therefore, CRP is a high sensitive biomarker that can be used for diagnosis, management, and prognosis of CHD [78].

Serum PCT level is significantly enhanced in cardio-diabetic patients versus healthy controls. Similar results have been obtained by Sinning et al. [78] who cited that patients with ACS have increased concentration of PCT. Likewise, Sponholz et al. [79] found that PCT level is increased in patients with cardiovascular events. Erren et al. [80] reported that the increased PCT level is linked to the extent of atherosclerosis in CAD patients and peripheral arterial disease. In atherosclerotic patients, ischemia and inflammatory processes cause PCT production. In addition, increased levels of PCT in the setting of CAD are more as a result of non-specific liberation of cytokine in the context of local tissue damage to myocardium due to ischemia and necrosis. This explains the association between PCT and low-grade inflammatory activity within the vascular wall caused by atherosclerosis. Schlitt et al. [81] found that PCT mRNA expression by peripheral blood mononuclear cells is 


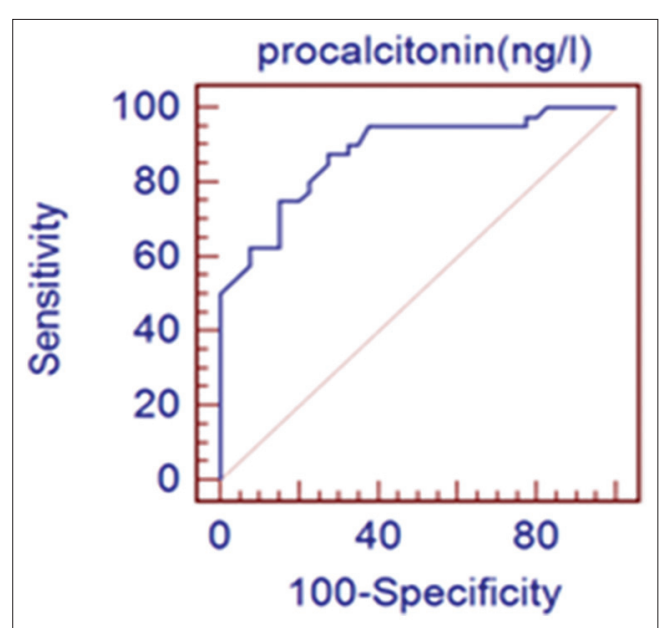

Fig. 5: Receiving operating characteristic curve for differentiation between diabetic and cardio-diabetic patients by procalcitonin $(\mathrm{p}=\mathbf{0 . 0 0 0 1})$

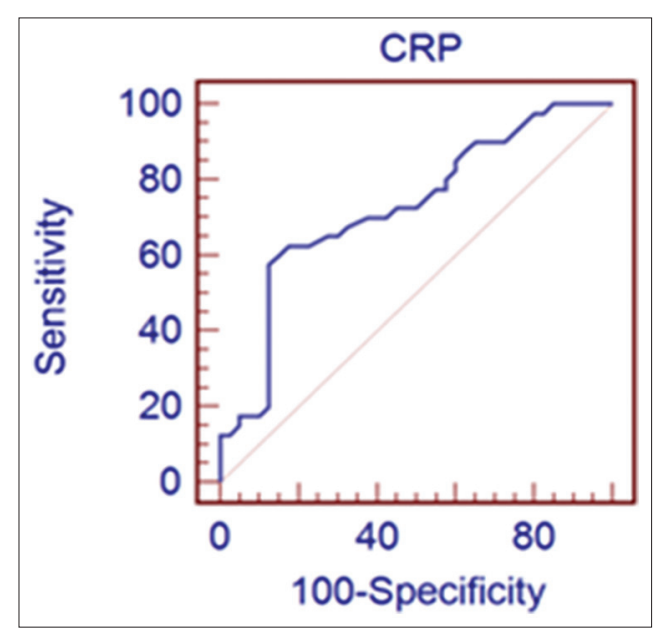

Fig. 6: Receiving operating characteristic curve for differentiation between diabetic and cardio-diabetic patients by $\mathrm{C}$-reactive protein $(\mathrm{p}=\mathbf{0 . 0 0 0 1})$

stimulated indirectly through proinflammatory cytokines (IL-1 $\beta$, IL-2, IL-6, and TNF- $\alpha$ ) which play an important role in the atherosclerotic process. These together explain the increased PCT concentration in diabetic patients with cardiovascular complication. Furthermore, patients with severe damage of myocardium after MI had elevated PCT level [82]. Remskar et al. [82] observed a relation between PCT level and heart failure as well as cardiogenic shock after AMI particularly in patients with PCT concentration $>0.5 \mathrm{ng} / \mathrm{ml}$.

Microalbumin level is significantly elevated in cardio-diabetic patients versus healthy individuals. This finding echoes those of pervious study of Klaus et al. [84] who demonstrated that patients who developed CHD during follow-up have higher urinary albumin excretion than controls. Furthermore, Jensen et al. [85] found a positive correlation between urinary albumin excretion rate and AMI. Several hypotheses explain the link between microalbuminuria and CVD. One of them suggests that a dysfunction of the vascular endothelium causes both microalbuminuria and CVD [86,87]. Endothelial impairment can be identified by any change in endothelial characteristics that is inappropriate with regard to the maintenance of organ function. Therefore, many kinds of endothelial impairment could be existed depending on which function is affected (e.g., the regulation of hemostasis and fibrinolysis, vasomotor activity, permeability to macromolecules, leukocyte adhesion, and vascular SMC proliferation). Generalized endothelial impairment is considered as a transducer of atherogenic risk factors and is thought to play an essential role in both development and progression of atherosclerosis. Therefore, the association of microalbuminuria with generalized endothelial impairment could explain why microalbuminuria strongly predicts CVD. Indeed, microalbuminuria in type 1 and type 2 diabetes is usually paralleled by endothelial impairment regarding the regulation of hemostasis, fibrinolysis, leukocyte adhesion, and no synthesis and/or availability [86]. Jager et al. [88] and Stehouwer et al. [89] mentioned that chronic, low-grade inflammation is related to the occurrence and progression of microalbuminuria and with risk for atherothrombotic disease. From the above considerations, endothelial impairment and chronic low-grade inflammation are essential candidates to explain the association between microalbuminuria and CVD.

In view of our data, significant positive correlation between serum PCT and cholesterol, TG, CRP, LDL, HbA1c, and FBG in diabetic patients has been found. Likewise, significant positive correlation has been detected between PCT and cholesterol, TG, CRP, and FBG in cardio-diabetic patients. These findings are in concert with the reports of Schiopu et al. [56] who found that PCT is associated with many of the already established cardiovascular risk factors (CRP, hypertension, diabetes, and renal function). Furthermore, Sponholz et al. [79] stated that PCT level is associated with CRP and TG concentrations in patient with CAD.

A significant positive correlation between serum CRP level and cholesterol, TG, FBG, HbA1c, and LDL in diabetic patients, and also between CRP and cholesterol, TG, FBG, and microalbumin in cardiodiabetic patients has been demonstrated. These results converge with the previous report of Seo et al. [90] which showed that levels of hs-CRP are significantly correlated with the level of glycosylated hemoglobin, LDL/HDL ratio, LDL/total cholesterol (TC) ratio, and TC/TG ratio in diabetic patients or patients with CVD. Furthermore, Bahceci et al. [91] observed positive correlation between serum hs-CRP and glycated hemoglobin in T2DM with or without CHD. Safiullah et al. [92] found that fasting plasma glucose, TC, LDL-cholesterol, and HbA1c are higher in diabetic patients with abnormal hs-CRP than the diabetic patients with normal hs-CRP.

ROC curve was done to detect the best cut-off value of serum PCT in diabetic and cardio-diabetic patients. It has proved that PCT at concentration $750 \mathrm{ng} / \mathrm{l}$ has $87.5 \%$ sensitivity and $72.5 \%$ specificity. Sponholz et al. [79] and Farzad et al. [93] revealed that procalcitonin level is high in patients with cardiovascular disease. In addition, the studies of Sponholz et al. [79] and Erren et al. [80] reported that the elevated PCT level is related to the extent of atherosclerosis in patients with $\mathrm{CAD}$ and peripheral arterial disease. In addition, these findings indicate that PCT is a biomarker of CAD in type 2 diabetic patients.

The best cut-off value of serum CRP in diabetic and cardio-diabetic patients was $42.1 \mathrm{mg} / \mathrm{l}$ with $62.5 \%$ sensitivity and $82.5 \%$ specificity. These results are comparable to the findings of Ridker [73] who mentioned that increased level of CRP is related to 8-fold increase in cardiovascular mortality. Furthermore, Bahceci et al. [91] found that hs-CRP levels are increased in patients with CHD, whether they are diabetic or non-diabetic than in controls, and the levels of hs-CRP in diabetic patient with CHD are also higher than patients with CHD only. These observations suggest that CRP is a biomarker of CAD in type 2 diabetic patients.

\section{CONCLUSION}

The present findings provide a clear evidence favoring the clinical value of measuring serum level of PCT and CRP as diagnostic candidates for cardiovascular complication in patients with T2DM.

\section{REFERENCES}

1. What is hemoglobin A1c? An analysis of glycated hemoglobins by electrospray ionization mass spectrometryClin Chem J. 272:International Diabetes Federation. IDF Diabetes Atlas. $7^{\text {th }}$ ed. 
Brussels, Belgium: International Diabetes Federation; 2015.

2. Wolfs MG, Hofker MH, Wijmenga C, van Haeften TW. Type 2 diabetes mellitus: New genetic insights will lead to new therapeutics. Curr Genomics 2009;10(2):110-8.

3. Somepalli M, Vinukonda K, Panugandla R, Shankar SB, Lakshmi C. Prevalence of acute cardiac and renal complications in poorly controlled diabetics and role of clinical pharmacist in modifying disease outcome in a tertiary care hospital. Int J Pharm Pharm Sci 2015;79(6):92-6.

4. Bartels DW, Davidson MH, Gong WC. Type 2 diabetes and cardiovascular disease: Reducing the risk. J Manag Care Pharm 2007;13 2 Suppl A: S2-15.

5. Fox CS, Golden SH, Anderson C, Bray GA, Burke LE, de Boer IH, et al. Update on prevention of cardiovascular disease in adults with type 2 diabetes mellitus in light of recent evidence: A scientific statement from the American Heart Association and the American Diabetes Association. Diabetes Care 2015;38(9):1777-803.

6. Bakker W, Eringa EC, Sipkema P, van Hinsbergh VW. Endothelial dysfunction and diabetes: Roles of hyperglycemia, impaired insulin signaling and obesity. Cell Tissue Res 2009;335(1):165-89.

7. Lebovitz HE. Insulin resistance-A common link between type 2 diabetes and cardiovascular disease. Diabetes Obes Metab 2006;8(3):237-49.

8. Souza JR, Oliveira RT, Blotta MH, Coelho OR. Serum levels of interleukin-6 (Il-6), interleukin-18 (Il-18) and C-reactive protein (CRP) in patients with type- 2 diabetes and acute coronary syndrome without ST-segment elevation. Arq Bras Cardiol 2008;90(2):86-90.

9. Al-Muhtaseb N, Al-Kaissi E, Muhi-Eldeen Z, Arafat T, AL-Muhtaseb S, Atiyah H. Oxidants and antioxidants as risk factors in young arabian male patients with acute myocardial infarction. Int J Pharm Pharm Sci 2016;8(6):273-7

10. Massaro KS, Costa SF, Leone C, Chamone DA. Procalcitonin (PCT) and $\mathrm{C}$-reactive protein (CRP) as severe systemic infection markers in febrile neutropenic adults. BMC Infect Dis 2007;7:137.

11. Yudkin JS, Stehouwer CD, Emeis JJ, Coppack SW. C-reactive protein in healthy subjects: Associations with obesity, insulin resistance, and endothelial dysfunction: A potential role for cytokines originating from adipose tissue? Arterioscler Thromb Vasc Biol 1999;19(4):972-8.

12. Gendrel D, Bohuon C. Procalcitonin as a marker of bacterial infection. Pediatr Infect Dis J 2000;19(8):679-87.

13. Maisner M. Procalcitonin - A New, Innovative Infection Parameter. Biochemical and Clinical Aspects. Stuttgart: Georg Thième; 2000.

14. Weglöhner W, Struck J, Fischer-Schulz C, Morgenthaler NG, Otto A, Bohuon $\mathrm{C}$, et al. Isolation and characterization of serum procalcitonin from patients with sepsis. Peptides 2001;22(12):2099-103.

15. Birnbaum RS, Mahoney WC, Burns DM, O'Neil JA, Miller RE, Roos BA. Identification of procalcitonin in a rat medullary thyroid carcinoma cell line. J Biol Chem 1984;259(5):2870-4

16. Jacobs JW, Lund PK, Potts JT Jr., Bell NH, Habener JF. Procalcitonin is a glycoprotein. J Biol Chem 1981;256(6):2803-7.

17. Nishikura T. Procalcitonin (PCT) production in a thyroidectomized patient. Intensive Care Med 1999;25(9):1031

18. Ittner L, Born W, Rau B, Steinbach G, Fischer JA. Circulating procalcitonin and cleavage products in septicaemia compared with medullary thyroid carcinoma. Eur J Endocrinol 2002;147(6):727-31

19. Meisner M, Müller V, Khakpour Z, Toegel E, Redl H. Induction of procalcitonin and proinflammatory cytokines in an anhepatic baboon endotoxin shock model. Shock 2003;19(2):187-90.

20. Ridker PM. Inflammatory biomarkers and risks of myocardial infarction, stroke, diabetes, and total mortality: Implications for longevity. Nutr Rev 2007;65(12 Pt 2):S253-9

21. Yarnell JW, Baker IA, Sweetnam PM, Bainton D, O'Brien JR, Whitehead PJ, et al. Fibrinogen, viscosity, and white blood cell count are major risk factors for ischemic heart disease. The Caerphilly and Speedwell collaborative heart disease studies. Circulation 1991;83(3):836-44.

22. Sentürk T, Cordan J, Baran I, Ozdemir B, Güllülü S, Aydinlar A, et al. Procalcitonin in patients with acute coronary syndrome: Correlation with high-sensitive C-reactive protein, prognosis and severity of coronary artery disease. Acta Cardiol 2007;62(2):135-41

23. Maruna P, Nedelníková K, Gürlich R. Physiology and genetics of procalcitonin. Physiol Res 2000;49 Suppl 1:S57-61.

24. Hatherill M, Tibby SM, Turner C, Ratnavel N, Murdoch IA. Procalcitonin and cytokine levels: Relationship to organ failure and mortality in pediatric septic shock. Crit Care Med 2000;28(7):2591-4.

25. Clec'h C, Fosse JP, Karoubi P, Vincent F, Chouahi I, Hamza L, et al. Differential diagnostic value of procalcitonin in surgical and medical patients with septic shock. Crit Care Med 2006;34(1):102-7.

26. Meisner M, Rauschmayer C, Schmidt J, Feyrer R, Cesnjevar R,
Bredle D, et al. Early increase of procalcitonin after cardiovascular surgery in patients with postoperative complications. Intensive Care Med 2002;28(8):1094-102

27. Thomas L, editor. Clinical Laboratory Diagnostics. $1^{\text {st }}$ ed. Frankfurt: TH-Books Verlagsgesellschaft; 1998. p. 131-7.

28. Richmond W. Preparation and properties of a cholesterol oxidase from Nocardia sp. and its application to the enzymatic assay of total cholesterol in serum. Clin Chem 1973;19(12):1350-6.

29. Assmann G. HDL-cholesterol precipitant. Randox Labs. Ltd. Crumlin Co. Antrim, N. Ireland. Internist 1979;20:559-64.

30. Okada M, Matsui H, Ito Y, Fujiwara A, Inano K. Low-density lipoprotein cholesterol can be chemically measured: A new superior method. J Lab Clin Med 1998;132(3):195-201.

31. Jacobs NJ, Van Denmark PJ. Triglycerides liquicolor. Arch Biochem Biophys 1960;88:250-5.

32. Trivelli LA, Ranney HM, Lai HT. Hemoglobin components in patients with diabetes mellitus. N Engl J Med 1971;284(7):353-7.

33. Hedlund P. Clinical and experimental studies on C-reactive protein (acute phase protein). Acta Med Scand Suppl 1961;361:1-71.

34. Mogensen CE, Schmitz A. Microalbumin for the quantitative determination of albumin in urine. Med Clin North Am 1988;72:1465-92.

35. Arkader R, Troster EJ, Lopes MR, Júnior RR, Carcillo JA, Leone C, et al. Procalcitonin does discriminate between sepsis and systemic inflammatory response syndrome. Arch Dis Child 2006;91(2):117-20.

36. Martín-Timón I, Sevillano-Collantes C, Segura-Galindo A, Del Cañizo-Gómez FJ. Type 2 diabetes and cardiovascular disease: Have all risk factors the same strength? World J Diabetes 2014;5(4):444-70.

37. Ali TM, Al Hadidi K. Chemerin is associated with markers of inflammation and predictors of atherosclerosis in Saudi subjects with metabolic syndrome and type 2 diabetes mellitus. Beni Suef Univ J Basic Appl Sci 2013;2:86-95.

38. Krauss RM. Lipids and lipoproteins in patients with type 2 diabetes. Diabetes Care 2004;27(6):1496-504

39. Boden G. Role of fatty acids in the pathogenesis of insulin resistance and NIDDM. Diabetes 1997;46(1):3-10.

40. Kelley DE, Simoneau JA. Impaired free fatty acid utilization by skeletal muscle in non-insulin-dependent diabetes mellitus. J Clin Invest 1994;94(6):2349-56.

41. Blüher M, Kratzsch J, Paschke R. Plasma levels of tumor necrosis factor-alpha, angiotensin II, growth hormone, and IGF-I are not elevated in insulin-resistant obese individuals with impaired glucose tolerance. Diabetes Care 2001;24(2):328-34.

42. Reaven GM, Chen YD. Role of abnormal free fatty acid metabolism in the development of non-insulin-dependent diabetes mellitus. Am J Med 1988;85(5A):106-12.

43. Tan CE, Foster L, Caslake MJ, Bedford D, Watson TD, McConnell M, et al. Relations between plasma lipids and postheparin plasma lipases and VLDL and LDL subfraction patterns in normolipemic men and women. Arterioscler Thromb Vasc Biol 1995;15(11):1839-48.

44. Zambon A, Austin MA, Brown BG, Hokanson JE, Brunzell JD. Effect of hepatic lipase on LDL in normal men and those with coronary artery disease. Arterioscler Thromb 1993;13(2):147-53.

45. Mayerson AB, Hundal RS, Dufour S, Lebon V, Befroy D, Cline GW, et al. The effects of rosiglitazone on insulin sensitivity, lipolysis, and hepatic and skeletal muscle triglyceride content in patients with type 2 diabetes. Diabetes 2002;51(3):797-802.

46. Miyazaki Y, Mahankali A, Matsuda M, Mahankali S, Hardies J, Cusi $\mathrm{K}$, et al. Effect of pioglitazone on abdominal fat distribution and insulin sensitivity in type 2 diabetic patients. J Clin Endocrinol Metab 2002;87(6):2784-91.

47. Makris K, Spanou L, Rambaouni-Antoneli A, Koniari K, Drakopoulos I, Rizos D, et al. Relationship between mean blood glucose and glycated haemoglobin in type 2 diabetic patients. Diabet Med 2008;25(2):174-8.

48. Peterson KP, Pavlovich JG, Goldstein D, Little R, England J, Peterson CM. What is hemoglobin A1c? An analysis of glycated hemoglobins by electrospray ionization mass spectrometry. Clin Chem 1998;44(9):1951-8.

49. Miedema K. Standardization of $\mathrm{HbAlc}$ and optimal range of monitoring. Scand J Clin Lab Invest Suppl 2005;240:61-72.

50. Belfki H, Ben Ali S, Bougatef S, Ben Ahmed D, Haddad N, Jmal A, et al. Association between C-reactive protein and type 2 diabetes in a Tunisian population. Inflammation 2012;35(2):684-9.

51. Morohoshi M, Fujisawa K, Uchimura I, Numano F. Glucose-dependent interleukin 6 and tumor necrosis factor production by human peripheral blood monocytes in vitro. Diabetes 1996;45(7):954-9.

52. Guha M, Bai W, Nadler JL, Natarajan R. Molecular mechanisms of tumor necrosis factor alpha gene expression in monocytic cells via 
hyperglycemia-induced oxidant stress-dependent and -independent pathways. J Biol Chem 2000;275(23):17728-39.

53. Grunfeld C, Feingold KR. Regulation of lipid metabolism by cytokines during host defense. Nutrition 1996;12 1 Suppl: S24-6.

54. Hirschfield GM, Pepys MB. C-reactive protein and cardiovascular disease: New insights from an old molecule. QJM 2003;96(11):793-807.

55. Soylemez MA, Seyment O, Yigit G. A novel mechanism between type II diabetes mellitus and procalcitonin gene expression. Mol Ther 2005;11:S346.

56. Schiopu A, Hedblad B, Engström G, Struck J, Morgenthaler NG, Melander O. Plasma procalcitonin and the risk of cardiovascular events and death: A prospective population-based study. J Intern Med 2012;272(5):484-91

57. Chowta NK, Pant P, Chowta MN. Microalbuminuria in diabetes mellitus: Association with age, sex, weight, and creatinine clearance. Indian J Nephrol 2009;19(2):53-6.

58. Mogensen CE, Neldam S, Tikkanen I, Oren S, Viskoper R, Watts RW, et al. Randomised controlled trial of dual blockade of renin-angiotensin system in patients with hypertension, microalbuminuria, and non-insulin dependent diabetes: The candesartan and lisinopril microalbuminuria (CALM) study. BMJ 2000;321(7274):1440-4.

59. Bucala R, Cerami A. Advanced glycosylation: Chemistry, biology, and implications for diabetes and aging. Adv Pharmacol 1992;23:1-34.

60. Tan KC, Chow WS, Ai VH, Metz C, Bucala R, Lam KS. Advanced glycation end products and endothelial dysfunction in type 2 diabetes. Diabetes Care 2002;25(6): 1055-9.

61. Haddad FH, Omari AA, Shamailah QM, Malkawi OM, Shehab AI, Mudabber HK, et al. Lipid profile in patients with coronary artery disease. Saudi Med J 2002;23(9):1054-8.

62. Celermajer DS. Endothelial dysfunction: Does it matter? Is it reversible? J Am Coll Cardiol 1997;30(2):325-33.

63. Dokken BB. The pathophysiology of cardiovascular disease and diabetes: Beyond blood pressure and lipids. Diabetes Spectr 2008;21:160-5.

64. Chan AC. Vitamin E and atherosclerosis. J Nutr 1998;128(10):1593-6.

65. Napoli C, Triggiani M, Palumbo G, Condorelli M, Chiariello M, Ambrosio G. Glycosylation enhances oxygen radical-induced modifications and decreases acetylhydrolase activity of human low density lipoprotein. Basic Res Cardiol 1997:92(2):96-105.

66. Cai A, Li G, Chen J, Li X, Wei X, Li L, et al. Glycated hemoglobin level is significantly associated with the severity of coronary artery disease in non-diabetic adults. Lipids Health Dis 2014;13:181

67. Brownlee M, Cerami A, Vlassara H. Advanced products of nonenzymatic glycosylation and the pathogenesis of diabetic vascular disease. Diabetes Metab Rev 1988;4(5):437-51.

68. Brownlee M. The pathobiology of diabetic complications: A unifying mechanism. Diabetes 2005;54(6):1615-25.

69. Nathan DM, Cleary PA, Backlund JY, Genuth SM, Lachin JM, Orchard TJ, et al. Intensive diabetes treatment and cardiovascular disease in patients with type 1 diabetes. N Engl J Med 2005;353(25):2643-53.

70. Geluk CA, Post WJ, Hillege HL, Tio RA, Tijssen JG, van Dijk RB, et al. C-reactive protein and angiographic characteristics of stable and unstable coronary artery disease: Data from the prospective PREVEND cohort. Atherosclerosis 2008;196(1):372-82.

71. Inoue T, Kato T, Uchida T, Sakuma M, Nakajima A, Shibazaki M, et al. Local release of C-reactive protein from vulnerable plaque or coronary arterial wall injured by stenting. J Am Coll Cardiol 2005;46(2):239-45.

72. Dunn EJ, Philippou H, Ariëns RA, Grant PJ. Molecular mechanisms involved in the resistance of fibrin to clot lysis by plasmin in subjects with type 2 diabetes mellitus. Diabetologia 2006;49(5):1071-80.

73. Ridker PM. Cardiology Patient Page. C-reactive protein: A simple test to help predict risk of heart attack and stroke. Circulation 2003;108(12):e81-5

74. Liang Z, Yu K, Wu B, Zhong Y, Zeng Q. The elevated levels of plasma chemerin and $\mathrm{C}$-reactive protein in patients with acute coronary syndrome. Xi Bao Yu Fen Zi Mian Yi Xue Za Zhi 2015;31(7):953-6.

75. Shrivastava AK, Singh HV, Raizada A, Singh SK. C-reactive protein, inflammation and coronaryheart disease. Egypt Heart J 2015;67:89-97.
76. Paffen E, DeMaat MP. C-reactive protein in atherosclerosis: A causal factor? Cardiovasc Res 2006;71(1):30-9

77. Pfützner A, Schöndorf T, Hanefeld M, Forst T. High-sensitivity C-reactive protein predicts cardiovascular risk in diabetic and nondiabetic patients: Effects of insulin-sensitizing treatment with pioglitazone. J Diabetes Sci Technol 2010;4(3):706-16.

78. Sinning CR, Sinning JM, Schulz A, Schnabel RB, Lubos E, Wild PS, et al. Association of serum procalcitonin with cardiovascular prognosis in coronary artery disease. Circ J 2011;75(5):1184-91.

79. Sponholz C, Sakr Y, Reinhart K, Brunkhorst F. Diagnostic value and prognostic implications of serum procalcitonin after cardiac surgery: a systematic review of the literature. Crit Care. 2006;10(5):145-55.

80. Erren M, Reinecke H, Junker R, Fobker M, Schulte H, Schurek JO, et al. Systemic inflammatory parameters in patients with atherosclerosis of the coronary and peripheral arteries. Arterioscler Thromb Vasc Biol 1999;19(10):2355-63.

81. Schlitt A, Heine GH, Blankenberg S, Espinola-Klein C, Dopheide JF, Bickel C, et al. CD14+ CD16+ monocytes in coronary artery disease and their relationship to serum TNF-alpha levels. Thromb Haemost 2004;92(2):419-24.

82. Ataoglu HE, Yilmaz F, Uzunhasan I, Cetin F, Temiz L, Döventas YE, et al. Procalcitonin: A novel cardiac marker with prognostic value in acute coronary syndrome. J Int Med Res 2010;38(1):52-61.

83. Remskar M, Horvat M, Hojker S, Noc M. Procalcitonin in patients with acute myocardial infarction. Wien Klin Wochenschr 2002;114(56):205-10.

84. Klausen K, Borch-Johnsen K, Feldt-Rasmussen B, Jensen G, Clausen P, Scharling H, et al. Very low levels of microalbuminuria are associated with increased risk of coronary heart disease and death independently of renal function, hypertension, and diabetes. Circulation 2004;110(1):32-5.

85. Jensen JS, Borch-Johnsen K, Feldt-Rasmussen B, Appleyard M, Jensen G. Urinary albumin excretion and history of acute myocardial infarction in a cross-sectional population study of 2,613 individuals. J Cardiovasc Risk 1997;4(2):121-5.

86. Stehouwer CD, Schalkwijk CG. Endothelial function and dysfunction. In: DeFronzo RA, Ferrannini E, Keen H, Zimmet P, Chichester JW, editors. International Textbook of Diabetes. $3^{\text {rd }}$ ed. New York: Wiley; 2004. p. 1409-23.

87. Stehouwer CD, Smulders YM. Microalbuminuria and risk for cardiovascular disease: Analysis of potential mechanisms. J Am Soc Nephrol 2006;17(8):2106-11.

88. Jager A, van Hinsbergh VW, Kostense PJ, Emeis JJ, Nijpels G, Dekker JM, et al. C-reactive protein and soluble vascular cell adhesion molecule-1 are associated with elevated urinary albumin excretion but do not explain its link with cardiovascular risk. Arterioscler Thromb Vasc Biol 2002;22(4):593-8.

89. Stehouwer CD, Gall MA, Twisk JW, Knudsen E, Emeis JJ, Parving HH. Increased urinary albumin excretion, endothelial dysfunction, and chronic low-grade inflammation in type 2 diabetes: Progressive, interrelated, and independently associated with risk of death. Diabetes 2002;51(4):1157-65

90. Seo SM, Baek SH, Jeon HK, Kang SM, Kim DS, Kim WS, et al. Correlations between the level of high-sensitivity C-reactive protein and cardiovascular risk factors in Korean adults with cardiovascular disease or diabetes mellitus: The CALLISTO study. J Atheroscler Thromb 2013;20(7):616-22.

91. Bahceci M, Tuzcu A, Ogun C, Canoruc N, Iltimur K, Aslan C. Is serum C-reactive protein concentration correlated with $\mathrm{HbAlc}$ and insulin resistance in Type 2 diabetic men with or without coronary heart disease? J Endocrinol Invest 2005;28(2):145-50.

92. Amanullah S, Jarari A, Govindan M, Basha MI, Khatheeja S. Association of hs-CRP with diabetic and non-diabetic individuals. Jordan J Biol Sci 2010;3:7-12.

93. Rahmani F, Rastian ML, Ghanbarzehi A, Behnammoghadam M, Abdollahimohammad A. Procalcitonin: A novel blood marker in coronary artery disease. Indian J Fundam Appl Life Sci 2015;5:2887-93. 